\title{
PELAKSANAAN MANAJEMEN MADRASAH PADA PONDOK PESANTREN DARUD DAKWAH WAL IRSYAD (DDI) PATTOJO KABUPATEN SOPPENG
}

\author{
H. Andi Achruh P1, Muhammad Iqbal ${ }^{2}$ \\ UIN Alauddin Makassar
}

\begin{abstract}
This study aims to analyze the implementation of madrasah management at the Darud Dakwah Wal Irsyad (DDI) Pattojo Islamic Boarding School, Soppeng Regency. In the process of collecting data, the author uses the method of observation and interviews with madrasah principals, madrasah teachers, madrasah staff, village heads, religious leaders, community leaders and youth leaders. Management is a way that is done so that other people can work and are willing to do something well and maximally and can use the best time possible. Furthermore, if the word management is associated with the word madrasah, then madrasah management is a way that is done professionally to raise and improve the madrasah by controlling and supervising all activities carried out. Making all elements in the madrasah work properly and optimally. Related to the management and development of madrasah management, namely by means of planning (planning), organizing (organizing), leadership (leading) and supervision (controlling). The implementation of madrasah management at the Darud Dakwah Wal Irsyad Pattojo boarding school in Soppeng Regency has been implemented and implemented quite well. So that the Darud Dakwah Wal Irsyad Pattojo boarding school, Soppeng Regency, still exists today and is still in great demand by various people. As for the role of the Darud Dakwah Wal Irsyad Pattojo boarding school, Soppeng Regency, after being studied from various perspectives, namely as a unifying element of society, development in the field of religion and development in the field of education. The author sees that the management of the Darud Dakwah Wal Irsyad Pattojo boarding school in Soppeng Regency has opportunities and challenges. With the development of sophisticated technology, all information systems and technology can become major capital in the development of these madrasas. However, there is a lack of human resources capable of adapting to these developments, so it still requires special training related to this management.
\end{abstract}

Keywords: Manajemen, Madrasah, Pondok Pesantren

\section{PENDAHULUAN}

Pada era globalisasi seperti sekarang ini, lembaga pendidikan dituntut untuk bisa eksis di tengah masyarakat yang semakin maju dan kritis. Persaingan lembaga pendidikan di tanah air semakin tinggi bahkan beberapa lembaga pendidikan luar negeri sudah ikut 
meramaikan bursa persaingan di Indonesia. Untuk itu, setiap lembaga pendidikan dituntut terus meningkatkan mutu termasuk lembaga pendidikan Islam seperti pondok pesantren. ${ }^{1}$ Pesantren merupakan lembaga pendidikan Islam tradisional tertua di Indonesia. Pesantren adalah lembaga yang bisa dikatakan merupakan wujud proses wajar perkembangan sistem pendidikan nasional. Menurut Nurcholis Madjid, secara histori pesantren tidak hanya identik dengan makna keislaman tetapi juga mengandung makna keaslian (indigenous) Indonesia. ${ }^{2}$ Karena, sebelum datangnya Islam ke Indonesia, lembaga serupa pesantren ini sudah ada di Indonesia dan Islam tinggal meneruskan, melestarikan dan memberikan ciri khas pendidikan Islam. Jadi pesantren merupakan hasil penyerapan akulturasi kebudayaan Hindu-Budha dan kebudayaan Islam kemudian menjelma menjadi suatu lembaga yang dikenal sebagai pesantren sekarang ini.

Pondok pesantren yang tersebar di pelosok-pelosok kepulauan Nusantara, turut pula menyumbangkan darma bakti dalam usaha mulia "character building" bangsa Indonesia. ${ }^{3}$ Ada beberapa nilai fundamental pendidikan pesantren yang selama ini jarang dipandang oleh kalangan yang menganggap dirinya modern, antara lain: (1) komitmen untuk tafaquh fi ad-din, nilai-nilai untuk teguh terhadap konsep dan ajaran agama; (2) pendidikan sepanjang waktu (long life education); (3) pendidikan integrative dengan mengkolaborasikan antara pendidikan formal dan nonformal (pendidikan seutuhnya, teks dan kontekstual atau teoritis dan praktis; (5) adanya keragaman, kebebasan, kemandirian dan tanggungjawab; (6) dalam pesantren diajarkan bagaimana hidup bermasyarakat. ${ }^{4}$ Itulah sebabnya Abdurrahman Wahid memposisikan pesantren sebagai subkultur tersendiri dalam pelataran kultural masyarakat dan bangsa Indonesia. Selaras dengan tuntutan modernitas dan keharusan merespons kenyataan negara-bangsa (nation-state), pesantren pun melakukan perubahan diri. Namun, karena otonomi dan ciri pluralitas yang melekat pada dirinya, perubahan yang terjadi besifat sporadis dan bahkan terkesan masih konservatif. Oleh karena itu, diskursus mengenai perubahan dan pembaruan senantiasa penting dilakukan secara intensif baik dari kalangan luar maupun dalam pesantren. ${ }^{5}$

Manajemen madrasah merupakan salah satu unit yang sangat penting pada pengelolaan pendidikan, karena keberhasilan suatu lembaga pendidikan juga sangat ditentukan oleh berfungsi atau tidaknya pengelolaan madrasah dan hubungan Masyarakat (Humas) di dunia pendidikan. Yaitu menunjang kegiatan manajemen untuk mencapai tujuan organisasi, bagaiamana membina hubungan harmonis antara organisasi dengan

\footnotetext{
${ }^{1}$ Indra Jati Sidi, Menuju Masyarakat Belajar, Menggagas Paradigma Baru Pendidikan, (Jakarta: Logos, 2013), h. 39.

${ }^{2}$ Nurcholish Madjid, Bilik-Bilik Pesantren: Sebuah Potret Perjalanan, (Cet. I; Jakarta: Paramadina, 1997), h. 3.

${ }^{3}$ Faisal Ismail, Percikan Pemikiran Islam, (Yogyakarta : Bina Usaha, 1984), h. 69.

${ }^{4}$ Chabib Thoha, "Mencari Format Pesantren Salaf", dalam Majalah Bulanan Rindang No. 9 Th.XXVI April 2001, h. 87.

${ }^{5}$ Abdurrahman Wahid, Pondok Persantren Masa Depan, dalam Marzuki Wahid, dkk. (Peny.) Pesantren Masa Depan: Wacana Pemberdayaan dan Transformasi Pesantren, (Cet. I; Bandung: Pustaka Hidayah, 1999), h. 13.
} 
publiknya, untuk mencegah terjadinya rintangan psikologis, baik yang ditimbulkan oleh pihak organisasi maupun oleh pihak publiknya. ${ }^{6}$

Al-Qur'an sebagai pedoman dasar Pendidikan Islam telah mengisyaratkan akan pentingnya membangun komunikasi antar sesama manusia, sebagaimana QS AliImran/3: 112

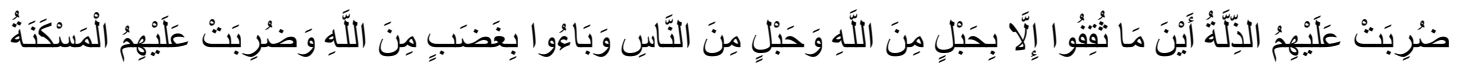

\section{Terjemahnya:}

Ditimpakan atas manusia kehinaan (kesengsaraan) dimana saja mereka berada, kecuali bila mereka selalu mengadakan hubungan dengan Allah dan manusia, dan mereka kembali mendapat kemurkaan dari Allah dan mereka diliputi kerendahan. ${ }^{7}$

Ayat tersebut menjelaskan bahwa manusia dituntut bekerjasama dengan yang lainnya dalam rangka mencapai tujuan hidup yang dicita-citakan dengan selalu mengharap ridho Allah. Pesantren Darud Dakwah Wal Irsyad Pattojo Kabupaten Soppeng yang menjadi pondok pesantren yang cukup tua di Kabupaten Soppeng terus berupaya untuk melakukan adaptasi terhadap perkembangan dan perubahan zaman dengan melakukan penguatan kelembagaan termasuk membangun sistem dan manajemen hubungan kemasyarakatan yang meliputi hubungan dengan berbagai pihak, mulai dari tokoh agama, akademisi, pemerintahan, hingga budayawan yang ada di Kabupaten Soppeng.

Partisipasi masyarakat pada dunia pendidikan tercantum pada Undang-Undang Republik Indonesia No. 20 Tahun 2003 tentang Sistem Pendidikan Nasional Pasal 9; bahwa masyarakat berkewajiban memberikan dukungan sumber daya dalam penyelenggaraan pendidikan. ${ }^{8}$ Posisi Pesantren Darud Dakwah Wal Irsyad Pattojo Kabupaten Soppeng dituntut untuk memberikan pencerahan bagi masyarakat Soppeng dengan menghadirkan lingkungan pendidikan Islam yang berkualitas utamanya di lingkungan pesantren sendiri. Masalah faktual yang menggerogoti peserta didik dan generasi muda tidak hanya terjadi di lingkungan lembaga pendidikan umum akan tetapi fenomena, kenakalan remaja, kekerasan antar pelajar, dan bahaya narkoba serta minuman keras juga tidak luput menjangkit di lingkungan pesantren termasuk di Darud Dakwah Wal Irsyad Pattojo Kabupaten Soppeng. Selain hal tersebut, Darud Dakwah Wal Irsyad Pattojo Kabupaten Soppeng dihadapkan pada tantangan peningkatan mutu lembaga pendidikan di tengah-tengah persaingan lembaga pesantren di Kabupaten Soppeng, baik aspek pengembangan kurikulum, standar pendidik, sarana dan prasarana lembaga pendidikan hingga sumber daya manusia yang dimilikinya. Mewujudkan manajemen

${ }^{6}$ Ruslan Rosady, Kiat dan Strategi Kampanye Public Relation, (Cet.I; Jakarta: RajaGrafindo, 1991), h. 9.

${ }^{7}$ Departemen Agama RI, Al-Qur'an dan Terjemahnya, (Cet. IV; Semarang: CV. Toha Putra, 2002), h. 80-81.

${ }^{8}$ Tim Redaksi Fokus Media, Undang-Undang Republik Indonesia, Nomor 20 Tahun 2003, Tentang Sistem Pendidikan Nasional, (Cet. II; Jakarta: Fokus Media, 2003), h. 5 
madrasah yang efektif tentu tidak lepas pada tantangan, hambatan, dan peluang yang ada. Pada posisi inilah maka penelitian ini akan mengkaji dan menganalisis peran strategis manajemen madrasah di pondok pesantren Darud Dakwah Wal Irsyad Pattojo Kabupaten Soppeng.

Berdasarkan uraian dalam pengantar diatas, maka penulis merumuskan pokok masalah yaitu sebagai berikut:

1. Bagaimana pelaksanaan manajemen madrasah pada pondok pesantren Darud Dakwah Wal Irsyad Pattojo Kabupaten Soppeng?

2. Bagaimana peran strategis manajemen madrasah di pondok pesantren Darud Dakwah Wal Irsyad Pattojo Kabupaten Soppeng?

3. Bagaimana peluang dan tantangan pelaksanaan manajemen madrasah di pondok pesantren Darud Dakwah Wal Irsyad Pattojo Kabupaten Soppeng?

\section{METODE PENELITIAN}

Penelitian ini adalah penelitian langsung yang bersifat kualitatif yang merupakan suatu bentuk penelitian ditujukan untuk mendeskripsikan fenomena-fenomena yang ada, baik fenomena alamiah maupun fenomena buatan manusia. Fenomena itu bisa berupa bentuk, aktivitas, karakteristik, perubahan, hubungan, kesamaan, dan perbedaan antara fenomena yang satu dengan fenomena lainnya. ${ }^{9}$ Dapat dikatakan bahwa penelitian kualitatif yang dimaksudkan ini adalah suatu upaya untuk mengungkapkan secara mendalam mengenai beberapa hal yang berkaitan dengan pelaksanaan manajemen madrasah di pondok pesantren Darud Dakwah Wal Irsyad Pattojo Kabupaten Soppeng .

Metode yang digunakan peneliti dalam penelitian ini adalah metode observasi dan interview. Observasi merupakan suatu pengamatan dan pencatatan sistematis terhadap fenomena yang diselidiki dalam hal ini penulis akan mengamati tentang perilaku atau aktivitas masyarakat. Sedangkan Interview yakni melakukan wawancara langsung kepada beberapa oknum masyarakat (tokoh masyarakat, tokoh agama, maupun pemerintah setempat) yang dianggap dapat memberikan keterangan tentang masalah yang akan dibahas.

\section{KAJIAN TEORI}

\section{A. Pengertian Manajemen dan Madrasah}

\section{Pengertian Manajemen}

Manajemen berasal dari bahasa Inggris yaitu management, dengan kata kerja tomanage yang secara umum berarti mengurusi, mengemudikan, mengelola, menjalankan, membina, atau memimpin, kata benda management dan manage yang

\footnotetext{
${ }^{9}$ Sukmadinata, Metode Penelitian Pendidikan (Cet. I; Bandung: Rosdakarya, 2006), h. 72.
} 
secara umum berarti orang melakukan kegiatan manajemen. Selain itu, ada pula ahhli yang berpendapat bahwa kata "majemen "berasal dari bahasa Latin, yaitu mantis yang berarti tangan dan agere yang berarti melakukan. ${ }^{10}$

Manajemen pada umumnya dikaitkan dengan aktivitas-aktivitas perencanaan, pengorganisasian, pengendalian, penempatan, pengarahan, pemotivasian, komunikasi dan pengambilan keputusan yang dilakukan oleh setiap organisasi dengan tujuan untuk mengkoordinasikan berbagi sumber-daya yang dimiliki oleh perusahaan sehingga akan menghasilkan suatu produk atau jasa secara efisien (Andrew F.Sikul). ${ }^{11}$

Manajemen juga dapat diartikan sebagai suatu cara yang dilakukan agar orang lain dapat bekerja dan bersedia melakukan sesuatu dengan baik dan maksimal serta dapat menggunakan waktu sebaik mungkin. Selanjutnya jika kata manajemen dikaitkan dengan kata organisasi, maka manajemen organisasi merupakan sebuah cara yang dilakukan secara professional untuk membangkitkan dan meningkatkan organisasi tersebut dengan cara mengendalikan dan mengawasi seluruh kegiatan yang dilakukan. Menjadikan seluruh elemen dalam orgaisasi tersebut bekerja secara baik dan maksimal .

\section{Pengertian Madrasah}

Pengertian secara bahasa madrasah berasal dari kata darasa (belajar) yang mempunyai 'isim makan' madrasah yang berarti tempat belajar atau sekolah. ${ }^{12}$ Jadi madrasah dapat diartikan sebagai tempat belajar bagi siswa atau mahasiswa (umat islam), karenanya kata madrasah tidak hanya diartikan dalam arti sempit tetapi juga dapat diartikan rumah, istana, kutab, perpustakaan, surau, masjid dan lain-lain, bahkan seorang ibu juga dapat disebutkan sebagai madrasah. ${ }^{13}$ Seorang ibu diartikan sebagai madrasah karena setiap bayi yang lahir, seorang ibu yang memiliki peran penting dan orang pertama yang memberikan pelajaran dan pendidikan kepada anaknya seperti mengajari berbicara, mengajari berjalan, mengajari makan, mengajari makan, mengajari akhlak mengajari ilmu agama dan lain sebagainya.

Madrasah mengandung arti tempat atau wahana anak mengenyam proses pembelajaran. Maksudnya adalah, di madrasah inilah anak menjalani proses belajar secara terarah, terpimpin, dan terkendali. Dengan demikian, secara teknis madsarah menggambarkan proses pembelajaran secara formal yang tidak berbeda dengan sekolah. Hanya dalam lingkup kultural, madarasah ini mempunyai konotasi spesifik. Yakni sebagai lembaga pendidikan yang dalam proses pembelajaran dan pendidikannya menitikberatkan pada persoalan agama. Kata madrasah, yang secara harfiah identik dengan sekolah agama, lambat laun sesuai dengan perjalan peradaban bangsa mengalami perubahan dalam meteri pelajaran yang diberikan kepada anak peserta didiknya,

\footnotetext{
${ }^{10}$ Donni Juni Priansa dan Sonny Suntani Setiana,Manajemen dan superfisi Pendidikan(Bandung:CF Pustaka Setia,2018) ,hlm.2.

${ }^{11}$ Eka Prihatin, Manajemen Peserta Didik (Bandung: Alfabeta, 2011), hlm 2.

${ }^{12}$ Ahmad Warson, Kamus Al-Munawwir Arab Indonesia ( Surabaya:Pustaka Progresif,1997), hal. 398

${ }^{13}$ Ahmad Ibrahim Syarif, Daulat Al-Rasul Fi Al-Madinah (Quait Dar al-bayan, 1972), hal. 76.
} 
madrasah dalam kegiatan pembelajarannya mulai menambah dengan mata pelajaran umum yang tidak melepaskan diri dari makna asalnya yang sesuai dengan ikatan budayanya, yakni budaya Islam. ${ }^{14}$

\section{B. Konsep Manajemen Pengelolaan Madrasah}

Manajemen di artikan sebagai pencapaian sasaran-sasaran organisasi dengan cara efektif dan efisien melalui perencanaan, pengorganisasian. kepemimpinan, dan pengendalian sumber daya organisasi. ${ }^{15}$

Pada hakikatnya, perancanaan adalah aktifitas pengambilan keputusan mengenai sasaran (objectivies) apa yang akan dicapai, tindakan apa yang akan diambil dalam rangka pencapaian tujuan atau sasaran dan siapa yang akan melaksanakan tugas-tugasnya. Artinya, pada kerangka ini, perencanaan adalah aktivitas memikirkan dan memilih rangkaian tindakan-tindakan yang tertuju pada pencapaianya maksud-maksud dan tujuan pendidikan.

Terkait dengan peran manajemen dalam pengelolaan madrasah, fungsi manajemen yang akan dibahas adalah Perencanaan (planning), Pengorganisasian (organizing), kepemimpinan (leading) dan Pengawasan (controlling). Maka dalam manajemen Madrasah, pimpinan merupakan seorang konseptor dalam menjalankan roda organisasi pendidikan untuk mencapai tujuan intitusional maupun Madrasah yaitu terciptanya insan kamil. Ia juga merupakan panglima pengawal yang melaksanakan fungsi kontrol berbagai pola pengajaran dan pendidikan di dalamnya. ${ }^{16}$ Penjelasan mengenai masing-masing kegiatan manajemen pengembangan lembaga Madrasah tersebut akan diuraikan pada bagian berikut:

\section{Perencanaan (planning) Madrasah}

Perencanaan atau planning merupakan suatu proses penentuan tujuan atau sasaran yang hendak dicapai dan menetapkan jalan dan sumber yang diperlukan untuk mencapai tujuan tersebut seefisien dan seefektif mungkin. Perencanaan merupakan sebuah cara yang ditempuh sebelum kegiatan terlaksana, sehingga sebuah organisasi akan terarah dengan baik. Artinya, pada kerangka ini, perencanaan adalah aktifitas memikirkan dan memilih rangkain tindakan yang tertuju pada tercapainya maksud-maksud dan tujuan pendidikan. ${ }^{17}$ Dapat pula dikatakan bahwa pimpinan harus mengetahui secara pasti tujuan jangka panjang, untuk kemudian rencana jangka menengah dan di atas jangka panjang menengah ini pula, ia harus menentukan perencanaan jangkah pendek. Perencanaan jangka pendek ini harus dirinci berdasarkan skala prioritas, mana yang harus dikerjakan terlebih dahulu dan secara bertahap serta terencana melaksakan tahap-tahap berikutnya

\footnotetext{
${ }^{14}$ Malik Fadjar, Madrasah dan Tantangan Modernitas, (Bandung: Miz, 1999) hal. 19

${ }^{15}$ Richard L.Darf,Manajemen ,Peterj,:Emil Salim Tinjung Desi Nursanti Dan Maryanmi Hermanto ,( Jakarta :Erlangga ,2002 )Hal.8.

${ }^{16}$ Sulistyorini,Manajemen Pendidikn Islam .OP,Cit,168 16

${ }^{17}$ M. Ngalim Purwanto, Administrasi Dan Supervisi Pendidikan, (Bandung: PT Remaja Rosdakarya, 2002) Hal.16.
} 
sampai tujuan jangka pendek itu dapat tercapai sepenuhnya, perlu diadakan evaluasi untuk menyempurnahkan langkah selanjutnya. ${ }^{18}$

Dari beberapa definisi tersebut dapat diambil konklusi khususnya yang berkaitan dengan perencanaan pengembangan lembaga Madrasah adalah kegiatan sistematis merancang sumber daya lembaga, meliputi mengenai apa yang akan dicapai, merumuskan metode dan tata cara untuk merealisasikan semaksimal mungkin serta kegiatan yang perlu dilakukan untuk mencapai tujuan dan memilih pelaksanaan kegiatan yang tepat bagi usaha pencapain tujuan Madrasah. Dasar dari fungsi manajemen dari pengembangan lembaga Madrasah ini sangat sesuai dengan nilai normatif yang dimunculkan dalam Al-Qur'an, yang salah satunya ada dalam surat al-hasyr ayat 18 yang menyatakan bahwa :

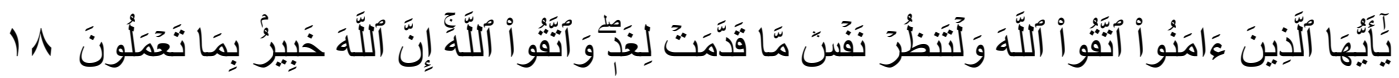

\section{Terjemahnya:}

Hai orang-orang yang beriman, bertaqwalah kepada Allah dan hendaklah setiap diri memperhatikan apa yang telah diperbuatkanya untuk hari eseok (ahirat), dan bertakwalah kepada Allah, sesungguhnya Allah maha mengetahui apa yang kamu kerjakan" (QS. Al-hasyr :18 )

Dari ayat diatas dapat diambil sebuah hikmah bahwa salah satu fungsi dari manajemen Madrasah yaitu perencanaan (planning), sehingga setiap orang yang beriman harus memiliki konsep kehidupan yang benar dan mempersiapkan diri untuk menghadapi hari esok. Hal ini berarti bahwa menganalisis dan mempersiapkan praktik Madrasah unuk masa depan merupakan bagian dari kesempurnaan agama bagi manusia. Jadi menurut penulis, dalam setiap perencanaan selalu terdapat tiga kegiatan yaitu :

a. Perumusan tujuan yang ingin dicapai

b. Pemilihan program untuk mencapai tujuan

c. Identifikasi dan pengarahan sumber yang jumlahnya selalu terbatas

2. Pengorganisasian (organizing) Madrasah

Pengorganisasian sebagai keseluruhan proses pengelompokan orang-orang, alatalat tugas, tanggungjawab atau wewenang sedemikian rupa, sehingga tercipta suatu organisasi yang dapat digerakkan sebagai suatu kesatuan dalam rangka mencapai tujuan yang telah ditetapkan. ${ }^{19}$

Definisi sederhana pengorganisasian menurut penulis adalah proses manajerial yang berkelanjutan. Sebagaimana kita ketahui teknelogi terus berkembang dan lingkungan organisasi dapat berubah. oleh karena itu manajer harus menyusaikan strategi

18 JB.Wahyudi, Dasar-Dasar manajemen Penyiaran (Jakarta: PT Gramedia Pustaka Utama 1994) Hal.71.

${ }^{19}$ Baharudin Dan Moh.Makin. Manajemen Madrasah ...OP. Cit, hal. 101. 
yang telah di susunnya sehingga tujuan dari organisasi tersebut tetap dapat di capai secara efektif dan efesien.

Menurut Syaiful Sagala, pengorganisasian dapat diartikan sebagai kegiatan membagi tugas-tugas pada orang yang terlibat dalam kerjasama pendidikan. Karena tugas-tugas ini demikian banyak dan tidak dapat diselesaikan oleh satu orang saja, maka tugas-tugas ini dibagi untuk dikerjakan oleh masing-masing organisasi. Kegiatan pengorganisasian adalah untuk menentukan siapa yang akan melaksanakan tugas sesuai prinsip pengorganisasian. ${ }^{20}$

Organisasi mengandung tiga elemen, yaitu kemampuan untuk bekerja sama, tujuan yang ingin dicapai dan komunikasi dalam penyelenggaraan fungsi pengorganisasian, sebaiknya dengan mengetahui dan menerapkan prinsip-prinsip oganisasi sehingga hasil penyelenggaraan fungsi pengorganisasian ini adalah tercipta suatu organisasi yang bentuk, struktur dan bagian-bagiannya disesuaikan dengan kebutuhan sekelompok orang yang terikat secara fomal dan terus menerus berinteraksi satu dengan yang lain dalam usaha pencapaian tujuan bersama.

Pengorganisasian akan lebih mudah dioperasikan jika disederhanakan kedalam suatu struktur organisasi. Struktur organisasi yang ditetapkan untuk diberlakukan oleh manajemen terwujud dalam salah satu tipe organisasi yang dikenal dewasa ini. Untuk menjatuhkan pilihan yang tepat pada satu tipe organisasi tertentu, perlu diketahui ciri dari masingmasing tipe. Setiap tipe organisasi mempunyai kelebihan dan kekurangan tertentu.

Proses pengorganisasian mempunyai beberapa tahap menurut Ilyasa dan Nanik yaitu:

a. Pemerincian pekerjaan, dengan menentukan tugas-tugas apa yang harus dilakukan untuk mencapai tujuan organisasi

b. Pembagian kerja, dengan membagi seluruh beban kerja menjadi kegiatan-kegiatan yang dapat dilaksanakan oleh perseorangan atau pekelompok. Orang yang akan diserahi tugas harus didasarkan pada kualifikasii, tidak dibebani terlalu berat dan tidak terlalu ringan.

c. Penyatuan pekerjaan, dengan menggabungkan pekerjaan para anggota dengan cara rasional dan efisien. Pengelompokan tugas yang saling berkaitan, jika organisasi sudah membesar atau kompleks. Penyatuan kerja ini biasanya disebut departementalisasi.

d. Koordinasi pekerjaan, dengan menetapkan mekanisme kerja untuk mengkoordinasikan pekerjaan dalam satu kesatuan yang harmonis. Pada setiap orang dan setiap bagian melaksanakan pekerjaan atau aktivitas, kemungkinan hal.49.

${ }^{20}$ Syaiful Sagala, Administrasi Pendidikan Kontemporer (Bandung : Bandung Alfabeta, 2008) 
timbul konflik diantara anggota dan mekanisme pengkoordinasian memungkinkan setip anggota organisasi untuk tetap bekeja secara efektif. ${ }^{21}$

3. Kepemimpinan (Leading) Madrasah

Memimpin (leading) merupakan fungsi ketiga dari manajemen. Leading ini berupa directing atau menunjukkan (guiding) dan memimpin orang-orang. Seorang pemimpin butuh hubungan atau komunikasi secara interpersonal dengan bawahan untuk mempengaruhi mereka.

Kepemimpinaan pendidikan merupakan salah satu hal yang penting untuk diterapkan di madrasah sebagai kelompok yang terorganisasi untuk mencapai tujuan pembelajaran Madrasah, sebab pada hakikatnya kepemimpinan pendidikan sebagai penentu keberhasilan segala aktivitas yang ada di lembaga Madrasah. Jadi dalam kerangka ini sangat jelas bahwa kepemimpinan Madrasah yang hendak dicapainya yaitu untuk membentuk manusia yang menjadi manusia paripurna, baik di dunia maupun di akhirat. $^{22}$ Dalam kerangka pemikiran Ibnu Taimiyah, lebih menyederhanakan tujuan Madrasah kedalam tujuan pokok yaitu :pertama, membentukindividumuslim, kedua, membentuk umat muslim, ketiga, dakwa Islam di dunia. ${ }^{23}$ Dalam Islam, kepemimpinan meliputi banyak hal. Menurut Fakih menyatakan mengenai pemimpin Islam. Seorang pemimpin dalam perspektif Islam memiliki fungsi ganda yaitu sebagai seorang khalifatullah (wakil Allah) di muka bumi yang harus merealisasikan misi sucinya sebagai pembawa rahmat bagi alam semesta. Dan sekaligus sebagai Abdullah (hamba Allah) yang patuh serta senantiasa terpanggil untuk mengabdikan segenap dedikasinya di jalan Allah.

Menurut C. A Weber mendefinisikan kepemimpinan pendidikan sebagai" the byprocess by whichpoeple are induced to move forward goalor purpose". ${ }^{24}$ Adapun kepemimpinan pendidikan menurut U. Husna Asmara di definisikan sebagai segenap kegiatan dalam usaha memengaruhi personel di lingkungan pendidikan pada situasi tertentu agar melalui kerjasama mau bekerja dengan penuh tanggung jawab dan ikhlas demi tercapainyaa tujuan pendidikan yang telah di tentukan. ${ }^{25}$ Untuk memahami dasar konseptual dalam perspektif Islam, berdasarkan pendekatan normative yang bersumber dari Al-Quran dan Al-Hadits, terdapat empat macam prinsip pokok kepemimpinan yaitu prinsip tanggung jawab (responsibility) dalam organisasi, prinsip etika tauhid, prinsip keadilan dan prinsip kesederhanaan. Sedangkan karakteristik yang dibutuhkan adalah memiliki aqidah islamiyah yang mantap, tasamuh (toleran), memiliki landasan kerjasama

${ }^{21}$ Mukhamad Ilyasin dan Nanik Nurhayati, Manejemen Madrasah (Malang: Aditya Media Publishing,2012), hal.138.

22 Djamaludin dan Abbdullah Aly, Kapita Selekta Madrasah: Untuk IAIN, STAIN,PTAIS Fakultas Tarbiyah Kompenen Mkk, (Bandung:CV Pustaka Setia, 1999), hal.15.

${ }^{23}$ Ahmad Warid Khan, Membebaskan Madrasah (Bandung: Istawa, 2002) hal.13.

${ }^{24}$ H.R.Suekarto Indrafachrudi, Bagaimana Memimpin Sekolah Yang Efktif (Bogor: Ghalia Indonesia, 2006) hal.1.

${ }^{25}$ Dadi Permadi Dan Daeng Arifin, Kepemimpinan Transformasional Kepala Sekolah Dan Komite Sekolah (Bandung,: PTSaarana Panca Karya Nusa, 2007) hal.45. 
dan solidaritas, mampu menghilangkan kultur organisasi, terbuka dan bebas dari penyakitjahid (reaksioner) serta jamid (beku berfikir).

4. Pengawasan (Controlling) Madrasah

Pengawasan (Controlling) ialah proses pengamatan dari pada pelaksanaan seluruh kegiatan organisasi untuk menjamin agar semua pekerjaan yang sedang dilakukan berjalan sesuai rencana yang ditetapkan. ${ }^{26}$ Dengan demikian, pengawasan manajemen adalah suatu usaha sistematis untuk menetapkan standar prestasi dengan sasaran perencanaan, merancang sistem umpan balik informasi, membandingkan prestasi aktual dengan standar yang telah ditetapkn. Menentukan apakah terdapat penyimpanaan dan mengukur signifikan tersebut dan mengambil tindakan perbaikan yang perlu untuk menjamin bahwa semua sumber daya perusahan yang sedang digunakan sedapat mungkin secara lebih efisien dan efektif guna mencapai perusahan. ${ }^{27}$

Proses dasar pengawasan terdiri dari tahap:

a. Menetapkan standar pelaksanaan pekerjaan

b. Pengukuran hasil atau pelaksanaan pekerjaan

Tahap kedua dari proses pengawasan (Nurdin Matry, 2008) adalah pengukuran hasil atau pelaksanaan. Metode dan teknik koreksinya dapat dilihat secara jelas pada klasifikasi fungsi-fungsi manajemen:

a. Perencanaan, yakni garis umpan balik proses manajemen dapat berwujud meninjau kembali rencana mengubah tujuan atau mengubah standar.

b. Pengorganisasian, dengan memeriksa apakah struktur organisasi yang ada itu cukup sesuai dengan standar, apakah tugasdan kewajiban telah dimengerti dengan baik, dan apakah diperlukan kembali penataan orang-orang.

c. Penataan staf, dengan memperbaiki sistem seleksi, memperbaiki sistem latihan dan menata kembali tugas-tugas.

d. Pengarahan yakni mengembangkan kepemimpinan yang lebih baik, meningkatkan motivasi, menjelaskan pekerjaan yang sukses, penyadaran akan tujuan secara keseluruhan apakah kerjasama antara pimpinan dan anak buah berada dalam standar. $^{28}$

Pengawasan akan berlangsung dengan efektif dan baik apabila memiliki ciriciri sebagai berikut:

1) Pengawasan harus merefleksikan sifat dari berbagai kegiatan yang diselenggarakan

${ }^{26}$ Ulbert Silalahi, Studi Tentang Ilmu Admistrasi (Bandung: CV Sinar Baru, 2000), hal. 175.

${ }^{27}$ Bedjo Siswanto, Manajemen Tenaga Kerja (Bandung: CV Sinar Baru, 1991), hal. 159.

${ }^{28}$ Nurdin Matry, Implementasi Dasar-Dasar Manajemen Sekolah Dalam Era Otonomi Daerah, (Makasar,Aksara Madani,2008) hal.357. 
2) Pengawasan harus segera memberikan petunjuk tentang kemungkinan adanya deviasi dari rencana

3) Pengawasan harus menunjukkan pengecualian pada titik-titikstrategis tertentu.

4) Obyektivitas dalam melakukan pengawasan.

5) Keluwesan pengawasan.

6) Pengawasan harus memperhitungkan pola dasar organisasi.

7) Efisiensi pelaksanaan pengawasan.

8) Pemahaman sistem pengawasan oleh semua pihak yang terlibat.

9) Pengawasan mencari apa yang tidak beres.

10) Pengawasan harus bersifat membimbing. ${ }^{29}$

\section{Peran Manajemen Madrasah}

Penerapan Manajemen Madrasah merupakan salah satu penyeimbang struktur kewenangan antara madrasah, pemerintah daerah pelaksanaan proses dan pusat sehingga manajemen menjadi lebih efisien. Kewenangan terhadap pembelajaran diserahkan kepada unit yang paling dekat dengan pelaksanaan proses pembelajaran itu sendiri yaitu madrasah. Disamping itu, untuk memberdayakan madrasah agar madrasah dapat melayani masyarakat secara maksimal sesuai dengan keinginan masyarakat tersebuat. ${ }^{30}$

Peran Manajemen Madrasah adalah untuk memandirikan atau memberdayakan madrasah melalui kewenangan (otonomi) kepada madrasah dan mendorong madrasah untuk melakukan pengambilan keputusan secara partisipatif. Secara terperinci Manajemen Madrasah memiliki tujuan sebagai berikut:

1. Meningkatkan mutu pendidikan melalui kemandirian dan inisiatif madrasah, atau peran madrasah dalam mengelola dan memberdayakan sumber daya yang tersedia.

2. Meningkatkan keperdulian warga madrasah, atau antara madrasah dan masyarakat dalam penyelenggaraan pendidikan melalui pengambilan keputusan bersama.

3. Meningkatkan tanggungjawab madrasah, atau antara madrasah kepada orangtua, juga pemerintah tentang mutu madrasah. ${ }^{31}$

4. Meningkatkan kompetensi yang sehat antar madrasah tentang mutu pendidikan yang akan dicapai. ${ }^{32}$

${ }^{29}$ Nanang Fatah, Landasan Manajemen Pendidikan, (Bandung: Remaja Rosda Karya, 2006) hal.102.

${ }^{30}$ Veithzal Rivai, Education Management, (Jakarta: Rajawali Pers, 2009), hal.148.

${ }^{31}$ Umul Aiman Lubis, Implementasi Manajemen Berbasis Sekolah dalam Meningkatkan Mutu Lulusan di SMA islam al-ulum terpadu Medan, Analytica Islamica, Vol. 4, No. 1, 2015, ISSN 167-186, hal. 6.

${ }^{32}$ Veitzal Rivai, Education Managemen, hal. 148 
Tujuan penerapan MBM yaitu memberikan keleluasaan kepada pihak pengelola pendidikan yang seharusnya dilakukan di madrasah masing-masing bahkan dalam mengambil keputusan pengelola pendidikan tidak harus menunggu dari pemerintah. MBM mengubah sistem pengambilan keputusan dengan memindahkan otoritas dalam pengambilan keputusan dan manajemen kepada setiap yang berkepentingan ditingkat lokal. ${ }^{33}$

Dari uraian diatas, terlihat bahwa Manajemen Berbasis Madrasah (MBM) bertujuan untuk membuat madrasah dapat lebih mandiri dalam memberdayakan madrasah melalui pemberian kewenangan (otonomi), fleksibilitas yang lebih besar terhadap madrasah dalam mengelola sumber daya dan mendorong partisipasi warga madrasah dan masyarakat untuk meningkatkan mutu pendidikan.

\section{HASIL PENELITIAN DAN PEMBAHASAN}

1. Pelaksanaan manajemen madrasah pada pondok pesantren Darud Dakwah Wal Irsyad Pattojo Kabupaten Soppeng

Pelaksanaan manajemen madrasah pada pondok pesantren Darud Dakwah Wal Irsyad Pattojo Kabupaten Soppeng telah diterapkan dan dilaksanakan dengan cukup baik. Sehingga pondok pesantren Darud Dakwah Wal Irsyad Pattojo Kabupaten Soppeng masih eksis sampai sekarang dan masih banyak diminati oleh berbagai masyarakat sebagai tempat beelajar yang baik untuk mereka.

Menurut Jumriana, S.Pd. ketika diwawancarai oleh penulis bahwa "Humas pondok pesantren Darud Dakwah Wal Irsyad Pattojo Kabupaten Soppeng melibatkan masyarakat dalam memajukan pondok pesantren karena masyarakat merupakan salah satu mitra dengan pondok pesantren. Masyarakat sebagai penduduk asli Kabupaten Soppeng yang berada di sekitar pondok pesantren memiliki peran penting terhadap perkembangan pondok pesantren. Karena pondok pesantren Darud Dakwah Wal Irsyad Pattojo Kabupaten Soppeng berada ditengah-tengah pemukiman warga dan berbaur langsung dengan masyarakat, maka pihak pondok tetap menjaga dan menjalin hubungan baik serta tetap menjalin hubungan komunikasi sebagai wujud perpanjangan informasi ke masyarakat luas.

Masyarakat memiliki peran penting dalam perwujudan manajemen madrasah, karena sebagai pusat informasi dari berbagai fluktuasi kondisi yang terjadi di sekitar pondok pesantren agar tetap bisa eksis serta mampu menghadapi masalah yang kemungkinan terjadi. Sistem pelaksaaan manajemen humas pondok pesantren Darud Dakwah Wal Irsyad Pattojo Kabupaten Soppeng mengikuti kultur budaya masyarakat, namun pembelajaran dalam Madrasah yang diberikan kepada santri tetap mengikuti kurikulum yang ditetapkan oleh pemerintah. Sedangkan terkait dengan pengajian kitab kepesantrenan tetap mengacu pada hajat keagamaan dan budaya yang terjadi dalam

${ }^{33}$ Umul Aiman Lubis, Implementasi Manajemen Berbasis Sekolah dalam Meningkatkan Mutu Lulusan di SMA islam al-ulum terpadu Medah, hal. 6 
lingkungan masyarakat setempat, sehingga semua masalah yang ditemukan masyakarat terkait dengan kehidupan beribadah dan bermuamalah telah terjawab dalam kitab yang dikaji dalam pengajian kepesantrenan tersebut.

\section{Peran strategis manajemen madrasah di pondok pesantren Darud Dakwah Wal Irsyad Pattojo Kabupaten Soppeng}

Memperhatikan awal mula sejarah berdirinya pesantren dengan membawa visi misi yang kental dengan agama dan pemersatu umat maka sungguh sangatlah besar peran strategis dari pondok pesantren Darud Dakwah Wal Irsyad Pattojo Kabupaten Soppeng. Hal ini dapat kita lihat baik itu pembinaan di bidang pendidikan maupun pembinaan masyarakat pada umumnya. Adapun peran pesantren Darud Dakwah Wal Irsyad Pattojo Kabupaten Soppeng di kaji dari berbagi sudut pandang sebagai berikut ini:

1. Pemersatu elemen masyarakat

Adanya pesantren membuat semua masyarakat merasa senang dan bangga karena di daerahnya ada sebuah pusat studi dimana mereka berlomba-lomba memasukkan anaknya ke pesantren Darud Dakwah Wal Irsyad Pattojo Kabupaten Soppeng. Kehadiran Pondok Pesantren Darud Dakwah Wal Irsyad Pattojo Kabupaten Soppeng membuat masyarakat semakin mudah mencarikan akses wadah pendidikan buat anak-anak mereka sehingga dari segi kuantitas ekonomi para warga merasa terbantu karena mereka tidak berpikir lagi untuk jauh-jauh mencari sekolah untuk anak-anak mereka. Dengan hadirnya pesantren maka persatuan dan kesatuan masyarakat semakin terjaga, perdamaian, dan merawat kecerdasan intelektual.

2. Pengembangan di bidang agama

Dibidang keagamaan masayarakat akan semakin teredukasi tentang bagaimana memahami agama dengan baik dan benar sehingga unsur-unsur dinamisme dan animism akan semakin terkikis dengan hadirnya pesantren memberikan edukasi agama yang tidak bertentangan dengan syariat yang sesungguhnya di dalam ajaran agama Islam.Kehadiran Pesantren Darud Dakwah Wal Irsyad Pattojo Kabupaten Soppeng memberikan hikmah akan pentingya edukasi keagamaan sehingga akidah masyarakat semakin mantab dan tetap terjaga dari hal-hal yang membuat masyarakat terjebak kedalam jurang kemurtadan. Hadirnya Pesantren Darud Dakwah Wal Irsyad Pattojo Kabupaten Soppeng membuat semakin hadirnya kaderisasi generasi dibidang keagamaan seperti lahirnya para muballig muda yang nantinya akan kembali kemasyrakat berdakwah.

3. Pengembangan di bidang Pendidikan

Pesantren selain sebagai tempat mencari ilmu agama, tafaqquh fi ad din juga merupakan tempat pengkaderan bagi para muballigh dalam menyebarkan agama islam yang sesungguhnya yang tidak bertentangan dengan syariat yang sesungguhnya. Hadirnya pesantren membuka jalan bagi perkembangan pendidikan, pengkajian, dan penalaran ilmu-ilmu agama dan ilmu umum di tengan 
masyarakat.Pondok Pesantren semakin kokoh dan eksis dengan banyaknya bukubuku yang menjadi bahan kajian para santri sehingga membuat ilmu pengetahuan para ulama dan santri santri akan semakin tersalurkan ke masyarakat luas. Jadi dengan adanya Pesantren dunia pendidikan semakin menteren $\mathrm{d}$ an seimbang antara ilmu umum dan ilmu agama.

3. Peluang dan tantangan pelaksanaan manajemen madrasah di pondok pesantren Darud Dakwah Wal Irsyad Pattojo Kabupaten Soppeng

Pondok pesantren Darud Dakwah Wal Irsyad Pattojo Kabupaten Soppeng merupakan salah satu tempat menimba ilmu agama yang berada di Kabupaten Soppeng. Madrasah ini telah berdiri dan eksis sekitar 48 tahun, tentunya ada beberapa kendala yang dihadapi selama berdiri dan aktif dalam menyebarkan ilmu agama.

Pada era milenial atau zaman modern saat sekarang, tentunya semua sistem akan mengalami perubahan terutama dalam hal tekhnologi. Pondok pesantren Darud Dakwah Wal Irsyad Pattojo Kabupaten Soppeng yang menjadi salah satu tempat sumber ilmu agama pada Kabupaten Soppeng sangat merasakan perubahan zaman tersebut. Saat masih era pra milenial atau dikenal dengan masa kolonial, tradisi menghormati kiyai atau guru masih sangat melekat erat pada seuluruh santri. Sedangkan saat sekarang, tradisi tersebut mulai pudar dan berkurang diakibatkan dengan perubahan zaman.

Manajemen madrasah pondok pesantren Darud Dakwah Wal Irsyad Pattojo Kabupaten Soppeng juga tidak lepas dari transisi perubahan zaman tersebut. Penulis melihat dalam manajemen pondok pesantren Darud Dakwah Wal Irsyad Pattojo Kabupaten Soppeng memiliki peluang dalam mengembangkan madrasahnya. Dengan perkembangan teknologi yang serba canggih, maka semua system informasi dapat menjadi modal besar dalam pengembangan madrasah tersebut. Seiring dengan perkembangan teknologi tersebut, tentu akan memberikan pula tantangan besar kepada manajemen pondok pesantren Darud Dakwah Wal Irsyad Pattojo Kabupaten Soppeng yaitu kurangnya sumber daya manusia yang mampu beradaptasi dengan perkembangan tersebut. Sumber daya manusia yang dimiliki pondok pesantren Darud Dakwah Wal Irsyad Pattojo Kabupaten Soppeng masih kurang mengetahui perkembangan teknologi yang sedang berkembang saat sekarang, sehingga masih membutuhkan pelatihan khusus terkait dengan manajemen tersebut.

\section{SIMPULAN}

Berdasarkan hasil penelitian di lapangan dan hasil analisis statistik dapat disimpulkan beberapa data penelitian yakni:

1. Pelaksanaan manajemen madrasah pada pondok pesantren Darud Dakwah Wal Irsyad Pattojo Kabupaten Soppeng telah diterapkan dan dilaksanakan dengan cukup baik. Sehingga pondok pesantren Darud Dakwah Wal Irsyad Pattojo Kabupaten Soppeng masih eksis sampai sekarang dan masih banyak diminati oleh berbagai masyarakat sebagai tempat beelajar yang baik untuk mereka. 
2. Peran pondok pesantren Darud Dakwah Wal Irsyad Pattojo Kabupaten Soppeng di kaji dari berbagi sudut pandang yaitu pemersatu elemen masyarakat, Pengembangan di bidang agama, Pengembangan di bidang Pendidikan

3. Manajemen madrasah pondok pesantren Darud Dakwah Wal Irsyad Pattojo Kabupaten Soppeng juga tidak lepas dari transisi perubahan zaman tersebut. Penulis melihat dalam manajemen pondok pesantren Darud Dakwah Wal Irsyad Pattojo Kabupaten Soppeng memiliki peluang dalam mengembangkan madrasahnya. Dengan perkembangan teknologi yang serba canggih, maka semua system informasi dapat menjadi modal besar dalam pengembangan madrasah tersebut. Seiring dengan perkembangan teknologi tersebut, tentu akan memberikan pula tantangan besar kepada manajemen pondok pesantren Darud Dakwah Wal Irsyad Pattojo Kabupaten Soppeng yaitu kurangnya sumber daya manusia yang mampu beradaptasi dengan perkembangan tersebut. Sumber daya manusia yang dimiliki pondok pesantren Darud Dakwah Wal Irsyad Pattojo Kabupaten Soppeng masih kurang mengetahui perkembangan teknologi yang sedang berkembang saat sekarang, sehingga masih membutuhkan pelatihan khusus terkait dengan manajemen tersebut.

\section{DAFTAR PUSTAKA}

Ali, Muhammad. Strategi Penelitian Pendidikan. Cet. II; Bandung Angkasa, 1993.

Asnawir, Administrasi Pendidikan. Cet.I; Pres Padang; Padang, 2005.

Departemen Agama RI, Al-Qur'an dan Terjemahnya. Cet. IV; Semarang: CV. Toha Putra, 2002.

Ismail, Faisal. Percikan Pemikiran Islam. Yogyakarta : Bina Usaha, 1984.

Komaruddin, Kamus Istilah Bandung: Angkasa, 1999.

Madjid, Nurcholish. Bilik-Bilik Pesantren: Sebuah Potret Perjalanan. Cet. I; Jakarta: Paramadina, 1997.

Mahfudz, M.A. Sahal. Nuansa Fiqh Sosial. Cet. I; Yogyakarta: LKiS, 1994.

Nata, Abuddin. Metodologi Studi Islam. Cet. XI; Jakarta: PT. Raja Grafindo Persada, 2004

Pusat Bahasa Departemen Pendidikan Nasional, Kamus Besar Bahasa Indonesia, Edisi Ketiga. Jakarta: Balai Pustaka, 2002.

Rosady, Ruslan. Kiat dan Strategi Kampanye Public Relation. Cet.I; Jakarta: RajaGrafindo, 1991. 
S. Nasution, Metode Research. Cet. III; Jakarta: Bumi Aksara, 2007.

Sidi, Indra Jati Menuju Masyarakat Belajar, Menggagas Paradigma Baru Pendidikan. Jakarta: Logos, 2013.

Sugiyono, Metode Penelitian Pendidikan Pendekatan Kualitatif, Kualitatif, dan R\&D. Bandung: Alfabeta, 2008.

Sukmadinata, Metode Penelitian Pendidikan. Cet. I; Bandung: Rosdakarya, 2006.

Thoha, Chabib. "Mencari Format Pesantren Salaf”, dalam Majalah Bulanan Rindang No. 9 Th.XXVI April 2001.

Tim Dosen Adiministrsi Pendidikan UPI, Manajemen Pendidikan. Cet. I; Bandung: Alfabeta, 2009

Tim Redaksi Fokus Media, Undang-Undang Republik Indonesia, Nomor 20 Tahun 2003, Tentang Sistem Pendidikan Nasional, Cet. II; Jakarta: Fokus Media, 2003.

Wahid, Abdurrahman. Pondok Persantren Masa Depan, dalam Marzuki Wahid, dkk. (Peny.) Pesantren Masa Depan: Wacana Pemberdayaan dan Transformasi Pesantren. Cet. I; Bandung: Pustaka Hidayah, 1999. 